\title{
WE PREPARE OUR STUDENTS FOR TEACHING THE FUTURE GENERATION
}

\author{
Agus Widyantoro \\ Yogyakarta State University, Indonesia \\ agus_widyantoro@uny.ac.id
}

\begin{abstract}
Lecturers in universities preparing for future teachers often teach materials which they think are up-to-date. However, is it true that what they teach may be useful for their students in their teaching in the future. Students may graduate in four to five years and they may not get jobs as soon as they leave universities. When they get a job as teachers, it might be five to six years after they graduate. At that time in schools, a new curriculum may be introduced, new theories on language teaching may emerge, and new problems may be faced. What they got from their lecturers in universities may not be relevant for solving the new problems. So, they need new knowledge or even new skills. This paper tries to explore the ways lecturers can do to prepare their students to face the 'real' challenges in their time of teaching.
\end{abstract}

Keywords: prepare, teaching, future generation

\section{INTRODUCTION}

Science and technology develops very fast. This has influenced all aspects of life. One of the aspects of life which is influenced by the fast development of science and technology is education. Technological change in the 21st century happens very fast and it seems to be in an almost exponential pace. (Scott \& Scott, 2010: 169).

Teachers in different levels of education will have to take into account this fast development of science and technology when they do not want to be left behind. The materials they teach to their students will have to be matched with current issues in science and technology. In this way, they will have to catch up with the development of science and technology.

With the development of information technology, the classroom also continues to evolve (Solomon, 2012: 89). Technology has a great influence on almost every aspect of the teaching learning process. For example, teachers may use online courses or give homework or assignments to students via the Internet. And, then, students will have to submit their assignment online. Teachers can set the due time for submitting the assignment, for example, on a certain date at 23:59 which is impossible to be done before. With the development of technology, it is now possible for teachers to have a kind of webinar (Biech, 2015: 9).

The influence of science and technology is also found in universities which produce teachers. Lecturers in these universities will have to prepare their students - the future teachers - to teach in an era which may be very different from the era they are teaching their students now. New

Some people say that the future is something which is not known clearly or sometimes called as the age of uncertainty. We do not know exactly what will happen in the next twenty years, for example. Certainly, there will be changes. In relation to education, new materials may be introduced, a new curriculum may be developed, new methods of teaching may be discovered, new media may be used, and still other new things will be introduced. 
The above statements may lead to the question: what must we do to teach our students? Will we teach them materials which may be out of date in a matter of years? And, still some other questions may emerge.

\section{FUTURE CHALLENGES}

A new century calls forth changed institutions (Clifford \& Friesen, 2003: 90). If we look at many aspects of life at present and compare them with those twentyyears ago, we will see that there may be fundamental changes in certain aspects of life and in some other aspects, no fundamental changes take place. Benade (2017: 24) called 'the unknowable future' located in a rapidly moving period of digitisation.

Teachers' needs are aligned with students' needs. Students' needs change over time. Something which might not be considered as essential needs in the past may now become essential needs. Some decades ago, computers were used only by big factories, but now, all people involved in education have to work with computers and so, computer literacy becomes an essential skill to be mastered now (Rosemary, et al., 2007: 14).

There may be new skills which students will have to master. For example, now we have digital media literacy (Trilling \& Fadel, 2009: xxiv) which did not exist some years ago. New skills, new materials, and new media may create new problems. And students will have to tackle all these new problems. The materials which we teach our students today will not be appropriate for solving the new problems. Students should be encouraged to be willing to try new ideas, to tackle tough problems, to create something new, to be rewarded by their own new ideas, to take risks, to fail and to try again. Teachers need to create an environment in which learners are engaged in their learning and construct their own knowledge. (Marbach-Ad, 2015: 29).

\subsection{Success in life}

A triggering question in relation to being successful in life is, "What does a successful life mean?". This question needs to be answered by those involved in the education system because education prepares young generation to be successful in life.

Maggino (2015) argued that satisfaction changes. He gave examples of the student satisfaction and of the community satisfaction. People used to feel satisfied only with simple things, but now, with the same things, people do not feel satisfied anymore. For example, people used to be happy when they had a mobile phone which could be used only for calling and sending short messages. However, these days, the same kind of mobile phones is considered as being old-fashioned. People need mobile phones with more features.

In relation to this, we will have to take into account that the students we teach today will face an era when the satisfaction may change. What does that mean? It means that we must prepare the students for teaching differently, which will satisfy the needs of their own students in the future.

\subsection{Success in learning}

The way students learn today is not the same as the way we teachers when we were at the university. Books were the only resource we could use in the past. Some students even did not have books because of the limited financial support from the parents. The materials taught by our previous teachers were available only in the forms of books. However, now, the materials can be in any different forms, such as 
e-books, audio materials, video materials which students can access easily. The available resources which can be accessed easily will influence the way people learn.

In the past, the learning process might happen only in the classrooms. However, in the future, a lot of other learning may occur outside the formal educational institutions (Tummons, 2009: 69).

Classrooms should not be considered as only places where students learn. They should also be good places for teachers to learn (Richards \& Farrell, 2005: 2). Teachers do not stop learning after they graduate from their university. When they start teaching, they should remember that their knowledge about language teaching and learning is not complete. Therefore, they will have to find opportunities to update their knowledge and skills.

The question about the success in learning may also be related to how someone learns. New materials and new skills may require new ways of learning. As mentioned before, learning can occur outside the classrooms. The 21 st century learning is characterized by the penetration of digital devices into schools (Bernade, 2017: 24). A study conducted by Andresen (2006: 5) concluded that lifelong learning is also influenced by the development of digital literacy and information literacy. Students will use the Internet to find information of a lot of things. Students may also learn through online courses.

There will be differences in the way students learn. For example, in an online course, students are required to develop self-disciplined. They have to be able to manage their time well, as they will have to submit the assignments on time, contribute to online discussions. Announcements may be broadcast online. So, students will need to access the Internet regularly in order not to be left behind. And the success in learning through online courses will be different from that through conventional teaching.

Even if the students will have to attend formal education, the situation may change. It is still possible that students will have to learn facts and principles, but this will happen not only for the sake of mastering the facts and principles. It is expected that after mastering the facts and principles, students will come up with new solutions to new problems. The materials should be developed in such a way that the students can learn them independently (Shea \& Stockford, 2015:17). The students can learn any time. With the help of technology, students can learn any time and anywhere. Learning does not begin when students enter schools and end when they leave schools

The content to be learned may also change. Students may not have to learn knowledge, but they have to learn skills or competencies (Andresen, 2006: 1). New jobs may emerge and new skills will have to be learned.

Not only will the learning proces change, the assessment may also change. At present, we know about "adaptive assessment", "performance assessment", "authentic assessment", "computer-based assessment", "internet-based assessment", and "communicative assessment" which did not exist a few years ago. So, it is possible that in the next few years, new forms of assessment may emerge.

1.3 Success in jobs

Education is also related to jobs. People attend education because they want to get better jobs. They want to get better jobs because they want to make their families live comfortably (Cann, 2007: 27). However, what makes their family live comfortably in the future may be quite different from what makes them happy now. 
So, what does it mean to be successful in future jobs? Will better education lead to better jobs? It seems that there is no guarantee that better education will automatically lead to better jobs. Why? As people are accustomed to learning independently, those who learn independently may have more knowledge than those who attend formal education. There is also no guarantee that the higher the educational level, the better the way a person deals with problems. Companies may also recruit those who have the required competencies even if they are not university graduates. This may create problems for universities as their graduates may no be recruited if they do not have the required competencies.

If we look at the jobs available today, we can see that some jobs which existed some years ago do not exist now. And, there are also new jobs - jobs which did not exist few years ago. From this, it can be anticipated that there might be new jobs in the near future, and so teachers will have to prepare to face the challenge to get the new jobs. If that happens in twenty years, this means that those who will try to find the jobs are those who are taught by our present students.

\section{CONCLUSION}

From what has been discussed before, it can be concluded that we, as teachers produniversities which produce future teachers will have to remember that our graduates will have to face very different students and problems. So, we should prepare our students to anticipate the possible problems in the future. What we teach today may be based on the knowledge and technology we can find today, but the students may find very different kind of knowledge and technology.

\section{REFERENCES}

Andresen, B.B. (2006). Impact of Lifelong E-learning. In Kumar, D. \& Turner, J. (eds.). (2006). Education for the 21st Century: Impact of ICT and Digital Resources. New York: Springer.

Barnett, R. (2007). A Will to Learn: Being a Student in an Age of Uncertainty. Berkshire: McGraw Hill.

Benade, L. (2017). Being a Teacher in the 21st Century: A Critical New Zealand Research Study. Auckland: Springer.

Biech, E. (2015). 101 Ways to Make Learning Active beyond the Classroom. New Jersey: Wiley.

Bryk, A.S. \& Driscoll, M.E. (1988). The High School as Community: Contextual Influences and Consequences for Students and Teachers. Washington Office of Educational Research and Improvement.

Cann, S. (2007). Building a successful 21st century music career. Boston: Thomson Course Technology.

Clifford, P. \& Friesen, S. (2003). Hard Fun: Teaching and Learning for the TwentyFirst Century. In Jardine, D.W., Clifford, P., \& Friesen, S. (eds). (2003). Back to the Basics of Teaching and Learning: Thinking the World Together. Mahwah: Lawrence Erlbaum Associates, Publishers.

Coates, M. (ed.).(2010). Shaping a New Educational Landscape: Exploring Possibilities for Education in the 21st Century. London: Continuum International Publishing Group.

Cohen, L. et al. (2010). A Guide to Teaching Practice. (Revised 5th edition). London: Routledge.

Day, C. (2004). A Passion for Teaching. London and New York: Routledge Falmer.

Dunlap, C.Z. \& Weisman, E.M. (2006). Helping English Language Learners Succeed. Huntington Beach: Shell Educational Publishing. 
Guskey, T.R. \& Passaro, P.D. (1994). Teacher Efficacy: A Study of Construct Dimensions. American Educational Research Journal, Vol. 31, 3, pp. 627-43

Heller, D. (2012). Curriculum on the Edge of Survival: How Schools Fail to Prepare Students for Membership in a Democracy. 2nd ed. Lanham: Rowman \& Littlefield Education.

Kotter, J.P. (1996). Leading Change. Boston: Harvard Business School Press.

Maggino, F. (ed.). (2015). A New Research Agenda for Improvements in Quality of Life. Heidelberg: Springer.

Marbach-Ad, G., Egan, L.C., \& Thompson, K.V. (2015). A Discipline-Based Teaching and Learning Center: A Model for Professional Development. Heidelberg: Springer.

National Research Council (2011). Assessing 21st Century Skills: Summary of a Workshop. Washington: The National Academies Press.

Richards, J.C. \& Farrell, T.S.C. (2005). Professional Development for Language Teachers: Strategies for Teacher Learning. Cambridge: Cambridge University Press.

Rosemary, C.A., et al. (2007). Designing Professional Development in Literacy: A Framework for Effective Instruction. New York: The Guilford Press.

Scott, D.E. \& Scott, S. (2010). Innovations in the Use of Technology and Teacher Professional Development. In Lindberg, J,O. \& Olofsson, A.D. (2010). Online Learning Communities and Teacher Professional Development: Methods for Improved Education Delivery. Hershey: Information Science Reference.

Shea, J. \& Stockford, A. (2015). Inspiring the Secondary Curriculum with Technology: Let the Students Do the Work. London: Routledge.

Solomon, A. et al. (2012). 100\% Student Success. Boston: Wadsworth Cengage Learning

Tummons, J. (2009). Curriculum Studies in the Lifelong Learning Sector. Exeter: Learning Matters. 